\title{
PEMANFAATAN KARBON SABUT KELAPA TERIMPREGNASI UNTUK MENGURANGI TEMBAGA(II) DALAM MEDIUM AIR
}

\author{
Roy Andreas, Uyi Sulaeman, Tien Setyaningtyas \\ Program Studi Kimia, Jurusan MIPA \\ Fakultas Sains dan Teknik, Universitas Jenderal Soedirman, Purwokerto
}

\begin{abstract}
This research is conducted to produce carbons from coconut fibre which approach to activated carbon clause continue with carbon surface modification and the adsorption examination to $\mathrm{Cu}(\mathrm{II})$ ions. The research consist of several phase. Carbon making of coconut fibre conducted by carbonization processes at $320-400^{\circ} \mathrm{C}$ with temperature interval $20^{\circ} \mathrm{C}$. Carbon yielded in characterized moisture content, ash content and its adsoprtion to iodium. The carbon surface modification conducted by loaded 2-mercaptobenzotiazol (MBT) on carbon. The adsorpsibility of carbon-MBT tested by influence of contact time, $\mathrm{pH}$, and the isoterm adsorption pattern. The result of the study showed carbonization of coconut fibre which approach the requirement of SII No.0258-89 gained at temperature $320^{\circ} \mathrm{C}$. In the present study equilibrium time of 10 minute and $\mathrm{pH}$ was found to be optimum for both adsorbent. While type of isothermal adsorption from carban and carbonMBT adsorbent followed the Langmuir adsorption pattern.
\end{abstract}

Keywords : Adsorption, $\mathrm{Cu}(\mathrm{II})$, carbon-MBT, coconut fibre

\section{PENDAHULUAN}

Tembaga merupakan salah satu logam berat beracun. Limbah tembaga dapat dihasilkan dari buangan industri seperti industri cat, industri pengolahan kayu, industri insektisida dan fungisida (Connell, 1995). Keracunan tembaga secara kronis pada manusia ditandai dengan timbulnya penyakit Wilson dan Kinsly.

Beberapa metode telah digunakan untuk menurunkan kelarutan logam berat tembaga. Salah satu cara untuk menanggulangi pencemaran logam berat tembaga adalah dengan proses adsorpsi menggunakan adsorben karbon. Beberapa faktor yang mempengaruhi kemampuan adsorpsi karbon adalah bahan dasar yang digunakan, metode pembuatan karbon, luas permukaan yang dimiliki dan gugusgugus aktif yang terdapat pada permukaan. Keaktifan dari permukaan adsorben terkait dengan impregnasi dari reagen kimia terhadap karbon. Pembuatan adsorben melalui proses impregnasi dengan menggunakan merkaptobenzotiazol (MBT) telah dilakukan. Filho, dkk (1995) mengimpregnasi MBT pada padatan pendukung lempung yang digunakan untuk memekatkan logam berat $\mathrm{Hg}$ (II), $\mathrm{Cd}$ (II), $\mathrm{Pb}$ (II), medium pelarut. Penelitian tentang proses MBT pada karbon aktif untuk pemekatan tembaga (II) telah dilakukan oleh Terada, dkk (1983).

Kelapa merupakan tumbuhan serba guna, hampir seluruh bagiannya dapat dimanfaatkan. Hasil utama dari tanaman kelapa adalah minyak kelapa, sedang jenis-jenis limbahnya adalah berupa: sabut, tempurung, air kelapa dan ampas daging kelapa. Sabut kelapa mengandung lignin dan selulosa (Suhardiyono, 1988). Susilowati (1996) mengungkapkan bahwa lignin dan selulosa dapat berfungsi sebagai penyerap atau adsorben. 


\section{METODE PENELITIAN Bahan}

Bahan yang digunakan dalam penelitian ini adalah sabut kelapa, larutan tembaga (II) berupa tembaga sulfat, akuades, larutan buffer fosfat dan buffer sitrat, larutan klorofom, polistirena, larutan aseton dan 2-merkaptobenzotianol (MBT).

\begin{abstract}
Alat
Alat yang digunakan dalam penelitian ini antara lain: eksikator, mortar; ayakan 100 mesh; neraca analitik; muffle furnance, spektroskopi serapan atom (AAS), $\mathrm{pH}$ meter, labu ukur 250 $\mathrm{mL}, 100 \mathrm{~mL}$ dan $10 \mathrm{~mL}$, pipet tetes, pipet seukuran $10 \mathrm{~mL}$, erlenmeyer $250 \mathrm{~mL}$, cawan porselen, corong, gelas piala, kertas saring dan pengaduk kaca.
\end{abstract}

\section{Prosedur Penelitian}

Preparasi adsorben

Pembuatan karbon sabut kelapa

Sabut kelapa dicuci dan dikeringkan dengan cara dijemur di bawah sinar matahari untuk menghilangkan air yang terdapat dalam sabut kelapa, kemudian dipotong-potong hingga kecil-kecil atau menjadi serbuk. Serbuk sabut kelapa lalu dikarbonisasi dalam furnace selama 3,5 jam dengan variasi suhu 320, 340, 360, 380, dan $400^{\circ} \mathrm{C}$. Karbon yang diperoleh pada suhu optimum dihaluskan dan diayak dengan ukuran 100 mesh untuk kemudian digunakan dalam penelitian

Impregnasi karbon sabut kelapa (Terada, 1983)

Karbon sabut kelapa sebanyak 50 gram direndam dalam $50 \mathrm{~mL}$ kloroform berisi polistirena $0,25 \%(\mathrm{~b} / \mathrm{v})$, diaduk dan pelarutnya diuapkan. Karbon selanjutnya direndam dalam $50 \mathrm{~mL}$ aseton berisi MBT $8 \%(\mathrm{~b} / \mathrm{v})$, diaduk dan pelarutnya diuapkan. Karbon hasil impregnasi dicuci dengan akuades dan dikeringkan pada suhu $80^{\circ} \mathrm{C}$ selama 5 jam

\section{Penentuan waktu kontak optimum}

Karbon dan karbon-MBT masingmasing sebanyak 0,1 gram ditambahkan dalam $10 \mathrm{~mL}$ larutan tembaga (II) 100 ppm pada $\mathrm{pH}$ netral dengan penambahan larutan buffer fosfat. Campuran dikocok pada variasi waktu kontak 30, 4050 dan 60 menit. Larutan disaring setelah pengocokan selesai dan filtrat diukur absorbansinya dengan AAS. Pengaruh waktu kontak digunakan sebagai waktu kesetimbangan adsorpsi. Sebagai pembanding digunakan data kesetimbangan adsorpsi serbuk sabut kelapa dan karbon tanpa impregnasi.

\section{Penentuan pH optimum}

Karbon dan karbon-MBT masingmasing sebanyak 0,1 gram dikocok dalam $10 \mathrm{~mL}$ larutan tembaga (II) 100 ppm pada waktu kontak optimum dengan variasi $\mathrm{pH} 2,3,4$, dan 5 dengan penambahan larutan buffer fosfat dan buffer sitrat. Larutan disaring setelah pengocokan dan filtrat yang diperoleh diukur absorbansinya dengan AAS dan dibuat kurva hubungan absorbansi terhadap $\mathrm{pH}$. Sebagai pembanding digunakan serbuk sabut kelapa dan karbon tanpa impregnasi.

\section{Penentuan pola isoterm adsorpsi}

Karbon dan karbon-MBT, masing-masing sebanyak 0,1 gram ditambahkan dalam $10 \mathrm{~mL}$ larutan tembaga (II) dan dikocok pada waktu kesetimbangan adsorpsi dan $\mathrm{pH}$ optimum. Konsentrasi larutan tembaga (II) dibuat bervariasi. Larutan disaring setelah pengocokkan dan filtrat diukur absorbansinya dengan AAS. Pola isoterm adsorpsi untuk masing-masing adsorben ditentukan 
HASIL DAN PEMBAHASAN

Preparasi Adsorben

Proses pembuatan karbon sabut kelapa meliputi dehidrasi dan karbonisasi. Pada tahap dehidrasi sabut kelapa yang sebelumnya telah dicuci, dikeringkan dengan cara dijemur di bawah sinar matahari. Proses ini dilakukan untuk mengurangi banyaknya asap pada proses karbonisasi. Sabut kelapa dikarbonisasi dalam muffle furnace. Karbonisasi dilakukan pada kisaran suhu 320 hingga $400^{\circ} \mathrm{C}$ selama 3,5 jam. Houston (1985) mengungkapkan bahwa pada suhu di atas $300^{\circ} \mathrm{C}$ pirolisis bahan akan menghasilkan pembentukan senyawa aromatik seperti fenol, dan senyawa volatil $\left(\mathrm{CH}_{4}\right.$ dan $\left.\mathrm{H}_{2}\right)$ dan akan dilepaskan dalam bentuk gas. Struktur senyawa aromatik ini akan menginisiasi pembentukan struktur berikutnya hingga membentuk pelat-pelat karbon heksagonal karbon amorf, sedangkan lepasnya senyawa volatil akan membuka pori-pori karbon. Karbonisasi di atas $400^{\circ} \mathrm{C}$ tidak dilakukan karena telah mengubah sabut kelapa menjadi abu.

Analisis kadar air, kadar abu dan daya serap karbon terhadap iod dilakukan untuk menentukan suhu karbonisasi sabut kelapa yang menghasilkan karbon yang memenuhi standar mutu arang (SII 02589-1989). Hasil analisis karbon dapat dilihat pada Tabel 1.

Tabel 1. Hasil analisis karbon sabut kelapa

\begin{tabular}{cccc}
\hline $\begin{array}{c}\text { Sampel karbon } \\
\left({ }^{\mathbf{0}} \mathbf{C}\right)\end{array}$ & $\begin{array}{c}\text { Kadar air } \\
(\%)\end{array}$ & $\begin{array}{c}\text { Kadar abu } \\
(\%)\end{array}$ & $\begin{array}{c}\text { Daya serap iod } \\
(\mathrm{mg} / \mathrm{g})\end{array}$ \\
\hline 320 & 1,7316 & 5,8993 & 872,4689 \\
340 & 2,8138 & 8,4355 & 700,6388 \\
360 & 6,7003 & 27,0173 & 674,2034 \\
380 & 8,0177 & 33,8839 & 608,1148 \\
400 & 2,3055 & 63,7608 & 581,6794 \\
SII 02589-1989 & maks 15 & maks 10 & $\min 750$ \\
\hline
\end{tabular}

Hasil penelitian dapat menunjukkan bahwa suhu karbonisasi karbon sabut kelapa yang menghasilkan karbon sesuai kriteria SII 0258-89 adalah pada $320^{\circ} \mathrm{C}$. Karbon yang dihasilkan pada suhu $320^{\circ} \mathrm{C}$ diayak dengan ukuran 100 mesh untuk digunakan pada tahap selanjutnya.

\section{Modifikasi Karbon}

Karbon sabut kelapa dimodifikasi permukaannya melalui impregnasi 2merkaptobenzotiazol (MBT). Impregnasi MBT bertujuan untuk menyalut karbon dengan gugus tiolat (R-SH). Menurut
Hassler (1963) adanya gugus-gugus aktif ini akan mempengaruhi kemampuan adsorpsi karbon. Keberhasilan impregnasi secara kuantitatif ditunjukkan dengan penentuan jumlah MBT yang terimpregnasi dalam karbon dengan menggunakan spektrofotometer UV-Vis. Jumlah MBT yang terimpregnasi dalam karbon yaitu sebanyak $0,4616 \mathrm{mg} / \mathrm{g}$.

\section{Penentuan Waktu Kesetimbangan Adsorpsi}

Waktu kesetimbangan adsorpsi dilakukan dengan cara mengontakkan 
atau mengocok campuran adsorben dengan larutan tembaga (II). Pengocokan dimaksudkan untuk memberikan kesempatan pada partikel karbon dan karbon terimpregnasi MBT untuk bersinggungan dengan adsorbat yang akan diserap. Berdasarkan variasi waktu yang dilakukan dalam penelitian diperoleh hasil analisis data AAS yang ditunjukkan pada Gambar 1.

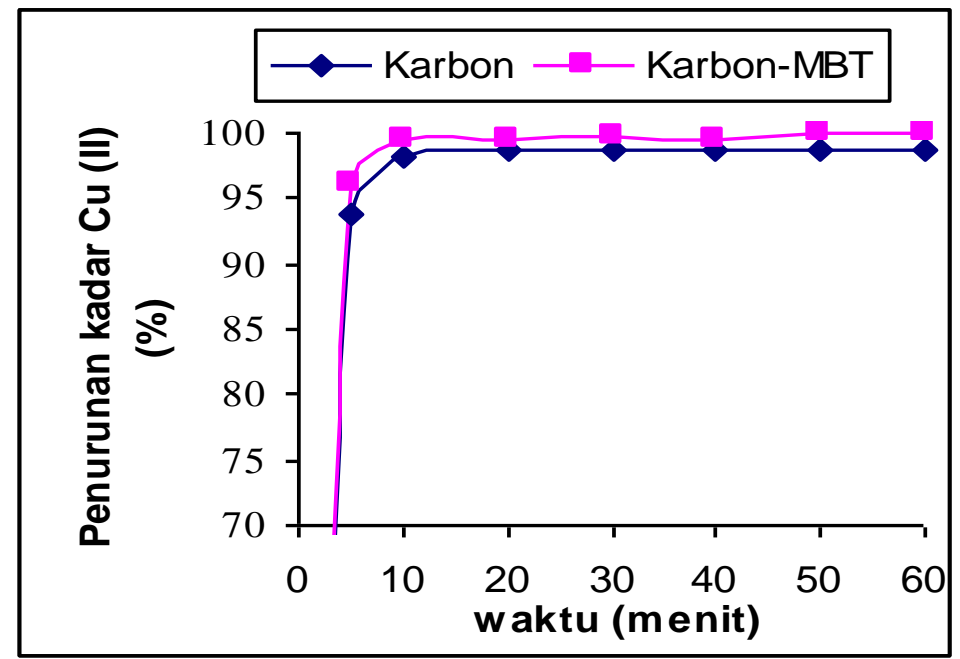

Gambar 1. Kurva penentuan waktu kesetimbangan

Gambar 1 menunjukkan bahwa adsorpsi Cu (II) oleh karbon dan karbon terimpregnasi MBT menunjukkan pola yang sama. Proses adsorpsi berlangsung sangat cepat, pada 5 menit pertama efisiensi penyerapan sudah lebih dari 90 $\%$. Kecepatan adsorpsi semakin berkurang dengan bertambahnya ion logam yang diserap. Pengocokan pada waktu diatas 10 menit kemudian tidak meningkatkan Adsorpsi Cu (II). Hal ini dapat terjadi karena permukaan adsorben telah jenuh.

\section{Penentuan pH Optimum}

Efek konsentrasi ion hidrogen dalam larutan ditentukan pada $\mathrm{pH}$ yang divariasikan dari 2 hingga 5. pengaruh pH terhadap adsorpsi $\mathrm{Cu}$ (II) oleh karbon diperlihatkan pada Gambar 2.

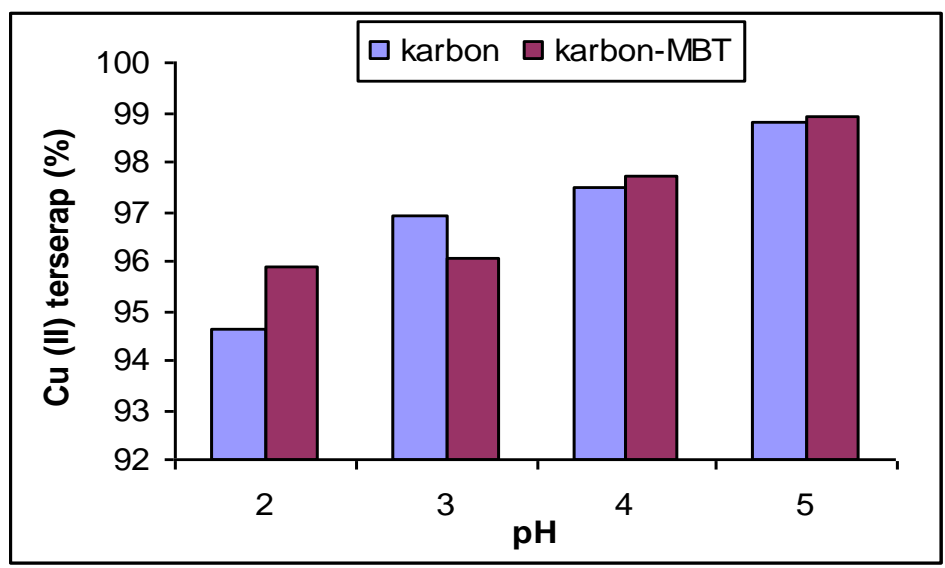

Gambar 2. Kurva pengaruh $\mathrm{pH}$ terhadap adsorpsi 
Nilai $\mathrm{pH}$ mempengaruhi spesiasi logam dalam air. Tembaga(II) terhidrasi dan membentuk kompleks dengan $\mathrm{H}_{2} \mathrm{O}$ sebagai $\left[\mathrm{Cu}\left(\mathrm{H}_{2} \mathrm{O}\right)_{4}\right]^{2+}$ dalam medium air. Pada kondisi $\mathrm{pH}$ rendah larutan cenderung lebih asam sehingga ketersediaan ion-ion $\mathrm{H}^{+}$yang cukup banyak akan mengganggu proses adsorpsi sehingga serapan $\mathrm{Cu}$ (II) menjadi sedikit. Adsorpsi $\mathrm{Cu}$ (II) oleh karbon dan karbon-MBT menunjukkan nilai optimum dicapai pada $\mathrm{pH} 5$ yaitu sebesar 98,7895\% untuk karbon dan 99,9315\% untuk karbon-MBT. Variasi pH dilakukan hingga pada nilai 5 karena di atas nilai tersebut tembaga akan mengendap sebagai $\mathrm{Cu}(\mathrm{OH})_{2}$. Berdasarkan $\mathrm{Ksp} \mathrm{Cu}(\mathrm{OH})_{2}\left(2,6 \times 10^{-19}\right)$, dengan asumsi konsentrasi $\mathrm{Cu}$ (II) 100 $\mathrm{mg} / \mathrm{L}$, secara teoritis tembaga akan mengendap pada $\mathrm{pH} \geq 5,23$ (Andreas, 2006).

\section{Penentuan Pola Isoterm Adsorpsi}

Keefektifan daya adsorpsi dinyatakan dengan suatu isoterm. Pada penelitian isoterm adsorpsi untuk karbon dan karbon-MBT dihitung baik dengan isoterm Langmuir maupun isoterm Freundlich. Isoterm Langmuir dihitung dengan persamaan sebagai berikut:

$$
\frac{C}{x / m}=\frac{1}{k_{1}}+\frac{k_{2}}{k_{1}} C
$$

Dimana $\mathrm{C} /(\mathrm{x} / \mathrm{m})$ sebagai sumbu y bila diplot terhadap $\mathrm{C}$ sebagai sumbu $\mathrm{x}$ akan memberikan garis lurus. Kurva isoterm Langmuir untuk karbon dan karbon-MBT diperlihatkan pada kurva. Nilai $\mathrm{R}^{2}$ yang diperoleh untuk karbon adalah 0,9997 dan untuk karbon-MBT adalah 0,998.

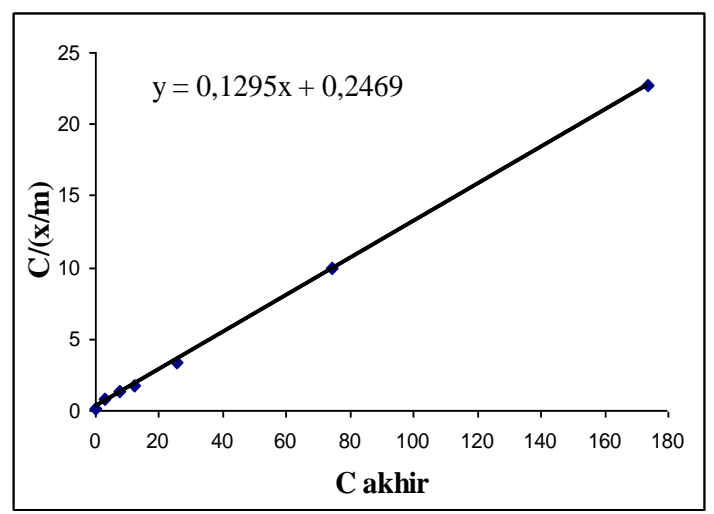

(a)

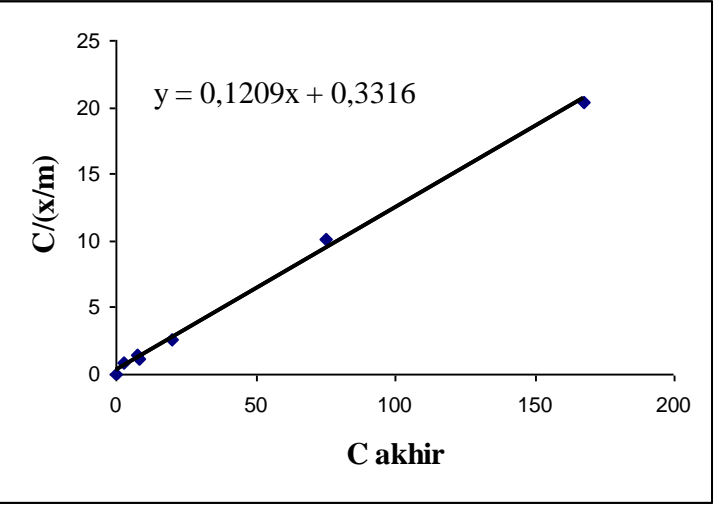

(b)

Gambar 3. Kurva isoterm adsorpsi Langmuir, (a). Kabon, (b). Karbon-MBT

Isoterm Freundlich dapat dihitung melalui persamaan:

$$
\log \frac{x}{m}=\log k+\frac{1}{n} \log C
$$

Plot $\log (\mathrm{x} / \mathrm{m})$ sebagai sumbu y terhadap $\log \mathrm{C}$ sebagai sumbu $\mathrm{x}$ akan diperoleh suatu garis lurus sehingga diketahui nilai intersep $\mathrm{k}$ dan slope $1 / \mathrm{n}$. Nilai $\mathrm{R}^{2}$ yang diperoleh untuk karbon sebesar 0,8947 dan untuk karbon-MBT 0,8674. 


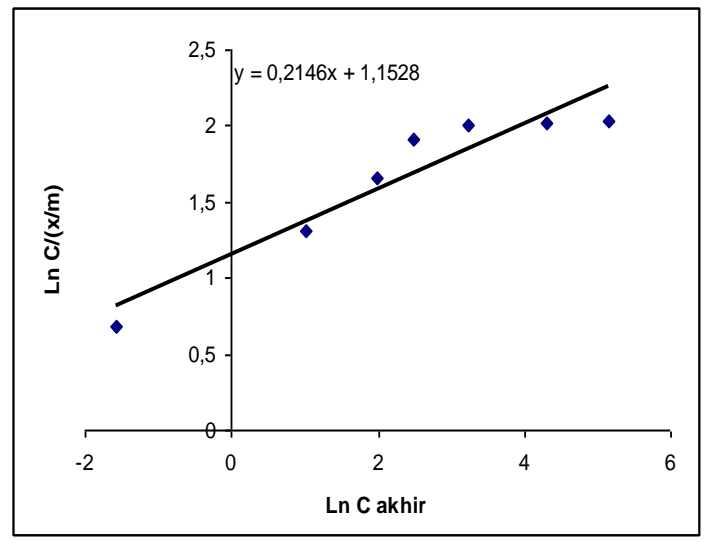

(a)

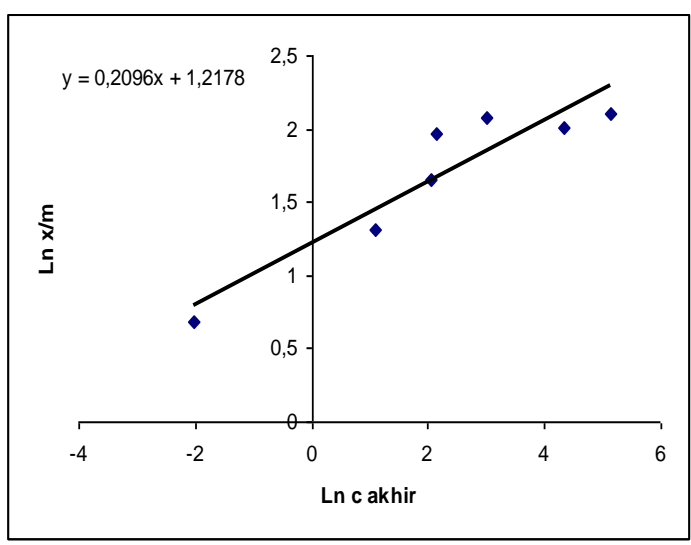

(b)

Gambar 4. Kurva isoterm Freundlich; (a). Karbon, (b). Karbon-MBT

Nilai $\mathrm{R}^{2}$ menunjukkan bahwa adsorpsi mengikuti pola isotherm Langmuir. Adsorpsi jenis ini mengindikasikan bahwa penyerapan terjadi melalui pembentukan lapis tunggal (monolayer), pengikatan adsorbat pada adsorben dapat terjadi secara fisika atau kimia dan mempunyai situs spesifik atau adsorpsi terlokalisasi.

\section{KESIMPULAN}

Berdasarkan penelitian ini dapat disimpulkan bahwa :

1. Suhu karbonisasi untuk menghasilkan karbon aktif standar adalah $320^{\circ} \mathrm{C}$ dengan kadar air dan kadar abu masing-masing sebesar 1,7316 dan $5,8993 \%$ sedangkan daya serap iod sebesar $872,4689 \mathrm{mg} / \mathrm{g}$.

2. Waktu kesetimbangan adsorpsi $\mathrm{Cu}$ (II) pada karbon dan karbon-MBT yaitu 10 menit dan $\mathrm{pH}$ optimumnya adalah pH 5.

3. Isoterm adsorpsi $\mathrm{Cu}(\mathrm{II})$ pada karbon dan karbon-MBT mengikuti persamaan isoterm adsorpsi Langmuir.

\section{DAFTAR PUSTAKA}

Connell, D.W. 1995. Bioakumulasi Senyawaan Xenobiotik. Penerbit Universitas Indonesia. Jakarta.

Filho, N.L.D. et all. 1994. 2Mercaptobenzothiazole Clay as Matrix for Sorption and Preconcentration of some Heavy Metals from Aquoeus Solution. Analytica Chemica Acta. Elsevier Science Publisher.

Hassler, L.W. 1963. Activated Carbon. $1^{\text {st }}$ Edition. Chemical Publishing Company Inc. New York.

Huheey, J.E. et all. 1993. Inorganic Chemistry: Principles of Structure and Reactivity. Fourth edition. Harper Collins College Publisher. USA.

SII 0258-89. 1989. Syarat Mutu Arang Aktif Indonesia.

Suhardiyono, L. 1988. Tanaman Kelapa: Budidaya dan Pemanfaatannya. Penerbit Kanisius. Jakarta.

Susilowati. 1996. Pemanfaatan Lignin dari Lindi Hitam Sebagai Adsorben Zat Warna Tekstil. Skripsi. Institut Teknologi 
Pemanfaatan Karbon Sabut ...(Andreas dkk.)

Bandung. Bandung (tidak dipublikasikan).

Terada, K. et all. 1983. Sorption of Copper (II) by some Complexing Agents Loaded on Various Supports. Analytica Chemica Acta. Elsevier Science Publisher. 